\title{
PENERAPAN MODEL PEMBELAJARAN ANCHORED INSTRUCTION UNTUK MENINGKATKAN KEMAMPUAN PEMECAHAN MASALAH PESERTA DIDIK PADA MATERI KALOR
}

\author{
Dedi Kuntadi', Hellen Lie Grace Ghautama1 \\ 1. Program Studi Pendidikan Fisika, Jurusan Pendidikan Matematika dan Ilmu \\ Pengetahuan Alam,Fakultas Tarbiyah dan Keguruan Universitas Islam Negeri Sunan \\ Gunung Djati Bandung
}

Email: dedikuntadi@uinsgd.ac.id

\begin{abstract}
ABSTRAK
Tujuan dari penelitian ini adalah untuk mengetahui peningkatan kemampuan pemecahan masalah fisika peserta didik. Metode penelitian yang digunakan adalah kuasi-eksperimen dengan desain non-equivalent control group. Populasi terdiri dari seluruh peserta didik kelas X SMA Yayasan Abdi Karya. Sampel terdiri dari 30 orang masingmasing untuk kelas dengan model Anchored Instruction dan kelas dengan model konvensional. Pengambilan sampel menggunakan teknik purposive sampling. Hasil analisis N-gain menunjukkan peningkatan kemampuan pemecahan masalah dengan model Anchored Instruction mencapai nilai rata-rata 0,70 terkategori tinggi dan model konvensional mencapai nilai rata-rata 0,59 terkategori sedang. Hasil pengujian hipotesis menggunakan Uji Mann-Whitney menunjukkan terdapat perbedaan peningkatan kemampuan pemecahan masalah antara peserta didik yang diterapkan model Anchored Instruction dengan model konvensional, model Anchored Instruction mengalami peningkatan kemampuan pemecahan masalah lebih tinggi dibandingkan model konvensional. fluida dinamis.
\end{abstract}

Kata kunci: Anchored Instruction, student's problem solving ability of Physics, heat and temperature.

\begin{abstract}
The purpose of study is to exam the influence of the anchored instruction model on student's problem solving ability of physics. The method used in this research is quasi-experiment and used non-equivalent control group design. Two samples consist of treatment class learned by using anchored instruction model and control class learned by using conventional model who were selected using purposive sampling techniques. The study was conducted in Abdi Karya senior high school Tanjungsari class $X$. The magnitude of the increase problem solving ability of students can be seen from the average $N$-Gain experiment class learners of 0.70 categorized being high and the average $N$-Gain control class learners of 0.59 categorized being middle. The effect of learning was analyzed by Mann Whitney U-test. The result showed that student's problem solving ability of Physics on treatment class is better than the control class.
\end{abstract}

Keywords: Anchored Instruction, student's problem solving ability of Physics, heat and temperature.

DOI: http://dx.doi.org/10.15575/jtlp.xxx.xxx

Received: xxxxxx ; Accepted: xxxxxx ; Published: $\operatorname{xxxxxxx}$ 


\section{PENDAHULUAN}

Perkembangan ilmu pengetahuan dan teknologi yang sangat pesat menuntut peningkatan kualitas sumber daya manusia yang siap bersaing di era globalisasi dan pasar bebas yang berdampak pada setiap aspek kehidupan. Aspek yang paling utama berpengaruh dalam mencetak sumber daya manusia yang berkualitas ini ialah salah satunya dalam aspek pendidikan. Dikatakan dalam (Sanjaya, 2006) bahwa pendidikan nasional berfungsi mengembangkan kemampuan dan membentuk watak serta peradaban bangsa yang bermartabat dalam rangka mencerdaskan kehidupan bangsa, bertujuan untuk berkembangnya potensi peserta didik agar menjadi manusia yang beriman dan bertakwa kepada Tuhan Yang Maha Esa, berakhlak mulia, sehat, berilmu, cakap, kreatif, mandiri, dan menjadi warga negara yang demokratis serta bertanggung jawab. Tujuan yang ingin dicapai dari tujuan kurikulum yang berbentuk kompetensi bukan hanya sekedar pemahaman akan materi pelajaran, akan tetapi bagaimana pemahaman dan penguasaan materi itu dapat mempengaruhi cara bertindak dan berperilaku dalam kehidupan sehari-hari.

Perlu adanya kemampuan pemecahan masalah yang benar untuk menyelesaikan permasalahan dalam kehidupan terkait konsepkonsep tersebut yang melibatkan pemikiran kritis, logis, dan sistematis untuk mencapai tujuan tersebut. Kemampuan pemecahan masalah ini memiliki peranan penting dalam pembelajaran, khususnya fisika, sebagai kemampuan awal bagi peserta didik dalam merumuskan konsep dan modal keberhasilan dalam menyelesaikan permasalahan dan mengembangkan ide/gagasan yang dimilikinya.

Dikatakan dalam (Trianto, 2014), peserta didik dalam belajar hanya menghafal konsep dan kurang mampu menggunakan konsep tersebut jika menemui masalah dalam kehidupan nyata yang berhubungan dengan konsep yang dimiliki. Sebagian besar peserta didik juga kurang mampu menghubungkan antara apa yang mereka pelajari dan bagaimana pengetahuan itu akan dimanfaatkan atau diaplikasikan pada situasi baru. Banyak kasus pelajar saat ini yang lebih memilih jalan pintas dalam menyelesaikan masalah di kehidupannya karena belum siap dalam menghadapi masalah yang ada. Disebutkan dalam (Nasution, 2009) bahwa peserta didik dalam memecahkan masalah harus berpikir, mencobakan hipotesis dan bila berhasil memecahkan masalah itu ia berarti telah mempelajari sesuatu yang baru. Kegiatan belajar selama ini hanya didominasi dengan sistem hafalan, sehingga peserta didik tidak paham penggunaannya dalam kehidupan. Sistem pembelajaran di sekolah masih didominasi dengan ceramah, meski pendidikan telah berkembang. Tidak heran peserta didik hanya hafal sesaat saja tanpa paham maknanya karena pembelajaran yang bersifat lisan verbal ini, sebagaimana seorang filusuf Cina Konvicius mengatakan,"Apa yang saya dengar saya lupa, apa yang saya lihat saya ingat, apa yang saya lakukan saya paham."

Berdasarkan hasil studi pendahuluan berupa wawancara yang dilakukan pada salah seorang guru fisika, diketahui bahwa SMA Yayasan Abdi Karya Tanjungsari menggunakan kurikulum KTSP dengan nilai KKM mata pelajaran Fisika untuk tingkat kelas X adalah 65. Menurut guru fisika, sebagian peserta didik memiliki keingintahuan pada fisika yang cukup besar terlihat dari semangat mereka mengerjakan tugas dari guru, namun banyak di antara mereka yang kesulitan dalam memahami materi fisika yang guru sampaikan. Seakan-akan materi yang disampaikan guru hanya "masuk telinga kiri dan keluar telinga kanan". Peneliti juga melakukan wawancara kepada peserta didik, mereka mengatakan bahwa sulit mempelajari fisika, banyak hafalan rumus yang rumit dan peserta didik tidak tau manfaat belajar fisika ini. Hal tersebut dilatarbelakangi oleh beberapa faktor diantaranya karena peserta didik kurang turut serta dalam proses pembelajaran dan penggunaan metode konvensional yang mendominasi pembelajaran di kelas.

Peneliti selanjutnya melakukan observasi langsung ke dalam kelas untuk melihat proses 
pembelajaran. Kegiatan pembelajaran berlangsung dengan tertib, namun pusat perhatian hanya tertuju pada guru saja. Peserta didik hanya mencatat apa yang disampaikan guru dan melakukan latihan soal dari buku paket. Kebanyakan peserta didik masih menerapkan sistem "menyalin" dari pekerjaan temannya. Terlihat bahwa pembelajaran di kelas masih belum memuaskan dan kemampuan pemecahan masalah yang merupakan bagian dari penalaran belum dapat dilatihkan secara maksimal.

Peneliti juga melakukan observasi dengan memberikan angket dan soal-soal dasar terkait kemampuan pemecahan masalah pada peserta didik yang sebelumnya telah mempelajari fisika. Data dari lembar observasi sampel penelitian kelas XI SMA Yayasan Abdi Karya Tanjungsari menunjukkan sebanyak $87,72 \%$ peserta didik tidak menyukai fisika dan sebanyak 90,48\% beranggapan fisika merupakan pelajaran yang sulit dan tidak menyenangkan.

Data hasil studi pendahuluan berupa tes tertulis berbentuk uraian terstruktur tentang pemecahan masalah menunjukkan peserta didik belum dapat memecahkan masalah dengan tepat. Hal tersebut dibuktikan dengan soal kemampuan pemecahan masalah yang diujikan kepada kelas XI yang sebelumnya telah menerima materi optik, kalor, dan kelistrikan, ternyata menunjukan nilai rata-rata terendah setiap tahap pemecahan masalah dialami peserta didik pada materi kalor. Hasil telaah kurikulum juga menunjukkan materi ini bertepatan dengan waktu penelitian yang akan dilaksanakan. Berdasarkan pemikiran tersebut, peneliti berinisiatif untuk melakukan penelitian dengan mengambil materi kalor.

Sesuai dengan karakteristik materi kalor, diperlukan suatu pembelajaran yang menghubungkan langsung dengan kenyataan sehingga kemampuan pemecahan masalah dapat dilatihkan. Materi kalor lebih tepat disajikan melalui metode pembelajaran non Konvensional, sehingga diperlukan sebuah model pembelajaran dengan tahapan yang jelas untuk dapat mengajak siswa secara aktif berpikir, bertanya jawab, berdiskusi, memecahkan masalah, dan mengasah keterampilan berpikirnya. Peneliti mencoba menggunakan model pembelajaran bermakna agar materi yang disampaikan dapat terlatihkan pada peserta didik dan diharapkan dapat meningkatkan kemampuan pemecahan masalah peserta didik. Salah satu bentuk model pembelajaran bermakna yaitu Anchored Instruction.

Peneliti menggunakan model pembelajaran Anchored Instruction dalam upaya meningkatkan kemampuan pemecahan masalah peserta didik sebagaimana terinspirasi dari beberapa jurnal diantaranya; dalam (Bransford, 1997) dikatakan bahwa model pembelajaran Anchored Instruction diperkenalkan oleh The Cognition and Technology Group at Vanderbilt (CTGV) dan berhubungan dengan teori konstruktivisme. Anchored Instruction hadir dengan menyajikan masalah dalam bentuk cerita yang dimaksud untuk "eksplorasi dan diskusi lebih baik daripada sekedar membaca atau melihat" dan esensi dari pendekatan ini adalah "anchor" atau situasi instruksional dalam konteks wilayah pemecahan masalah.

Anchored Instruction bersifat menanamkan semua informasi yang dibutuhkan untuk menyelesaikan masalah, memberikan kemudahan dalam pembelajaran dengan waktu dan sumber yang terbatas. Masalah yang disampaikan dalam bentuk cerita yang digunakan dalam anchor dimaksudkan untuk menanamkan informasi (dapat berupa video atau multimedia interaktif lain terutama bersifat visual). Model dari cerita yang digunakan anchor, diidentifikasikan dengan langkah untuk pemecahan masalah yang kemudian diatur ke dalam susunan cerita (Oliver, 1999).

Penelitian dengan menggunakan Anchored Instruction yang dilakukan oleh (Hafizah, 2014) menyatakan bahwa model pembelajaran Anchored Instruction dapat meningkatkan pemahaman konsep dan kemampuan pemecahan masalah siswa pada materi kalor. Hal ini sejalan dengan apa yang disampaikan (Kovalchick dan Dawson, 2004) bahwa pembelajaran Anchored Instruction dapat 
memberikan keuntungan. Keuntungan tersebut siswa mampu menjadi pemecah masalah sendiri dengan mengembangkan pemahaman secara mendalam melalui masalah yang telah dikemas sedemikian rupa diawal pembelajaran dan hasil kolaborasi siswa dalam diskusi yang dilakukan.

Diharapkan pada penelitian yang dilakukan penulis, model Anchored Instruction dapat meningkatkan kemampuan pemecahan masalah peserta didik pada materi kalor. Adapun hipotesis penelitian ini adalah terdapat perbedaan kemampuan pemecahan masalah peserta didik pada materi kalor antara yang diterapkan model pembelajaran Anchored Instruction dan yang diterapkan model konvensional. Kemampuan pemecahan masalah peserta didik dengan model pembelajaran Anchored Instruction lebih tinggi dibandingkan dengan model konvensional.

Tahapan model pembelajaran dalam Anchored Instruction diadaptasi dari tahapan yang dikemukakan oleh (Shyu dan Cindy, 2000) yaitu, pemberian masalah yang kompleks (presents a complex problem), bekerja sama (cooperate with others), penyelesaian masalah (solve problem), diskusi (discuss), membandingkan perspektif (comparative perspective).

Pengukuran kemampuan pemecahan masalah pada penelitian ini merujuk pada indikator yang disampaikan dalam (Tawil dan Liliasari, 2013) yaitu, memahami masalah, mengumpulkan data, merumuskan hipotesis, menilai hipotesis, menguji hipotesis, dan menyimpulkan.

\section{METODE PENELITIAN}

Penelitian ini merupakan penelitian kuasi eksperimen dengan menggunakan dua kelas yaitu satu kelas eksperimen dengan model pembelajaran Anchored Instruction dan satu kelas kontrol dengan model konvensional. Pokok bahasan penelitian ini adalah kalor. Desain penelitian yang digunakan adalah non-equivalen control group design. Populasi penelitian adalah seluruh peserta didik kelas X SMA Yayasan Abdi Karya Tanjungsari yang terdiri dari tiga kelas. Sampel dipilih dengan teknik purposive sampling.

Instrumen perlakuan meliputi silabus, RPP, Lembar observasi dan LKPD yang telah divalidasi oleh dua orang dosen. Instrumen tes kemampuan pemecahan masalah berupa 10 soal uraian terbatas yang telah dilakukan uji coba untuk menentukan validitas, reliabilitas, daya pembeda, dan tingkat kesukarannya.

Analisis data dilakukan dengan menggunakan uji Mann-Whitney. Sebelum dilakukan pengujian hipotesis data dilakukan uji prasyarat, yaitu uji normalitas dan uji homogenitas varians.

\section{HASIL DAN PEMBAHASAN}

Proses pembelajaran berlangsung tiga pertemuan dan keterlaksanaan diobservasi oleh tiga orang observer. Adapun persentase keterlaksanaan pembelajaran dapat dilihat pada Tabel 1.

Tabel 1. Persentase Keterlaksanaan Proses Pembelajaran

\begin{tabular}{|c|c|c|c|c|c|c|c|c|}
\hline \multirow{3}{*}{ 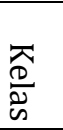 } & \multicolumn{6}{|c|}{ Pertemuan } & \multirow{2}{*}{\multicolumn{2}{|c|}{ Rata-rata }} \\
\hline & \multicolumn{2}{|c|}{1} & \multicolumn{2}{|c|}{2} & \multicolumn{2}{|c|}{3} & & \\
\hline & $G$ & $S$ & $G$ & $S$ & $G$ & $\mathrm{~S}$ & $G$ & $\mathrm{~S}$ \\
\hline$E$ & 72 & 68 & 87 & 86 & 96 & 94 & 85 & 83 \\
\hline $\mathrm{K}$ & 86 & 79 & 93 & 86 & 95 & 92 & 91 & 86 \\
\hline \multicolumn{9}{|c|}{ Keterangan: } \\
\hline $\begin{array}{l}E: \\
K: \\
G: C \\
S: S\end{array}$ & $\begin{array}{l}\text { peri } \\
\text { itrol } \\
\text { u } \\
\text { wa }\end{array}$ & $\begin{array}{l}\text { nen } \\
\text { (kon }\end{array}$ & $\begin{array}{l}\text { Anch } \\
\text { ens }\end{array}$ & $\begin{array}{l}\text { ored } \\
\text { onal) }\end{array}$ & nstr & ctior & & \\
\hline
\end{tabular}

Persentase pada Tabel 1 menunjukkan proses pembelajaran terkategori sangat baik untuk kelas kontrol dan terkategori baik untuk kelas eksperimen. Dapat dikatakan peningkatan kemampuan pemecahan masalah fisika peserta didik terjadi karena proses pembelajaran ini.

Menjawab rumusan masalah kedua dilakukan dengan Uji Mann Whitney yang dilihat dari peningkatan $\mathrm{N}$-gain yang diperoleh. Data 
kemampuan pemecahan masalah fisika peserta didik diperoleh melalui peningkatan dari tes awal ke tes akhir yang dilihat dari pencapaian Ngain. Sebelum dilakukan pengujian hipotesis, data awal tersebut dilakukan uji normalitas dan uji homogenitas varians. Uji normalitas menujukkan data tidak normal dan uji homogenitas varians menunjukkan data terdistribusi homogen, sehingga pengujian hipotesis menggunakan uji Mann-Whitney.

Hasil uji Mann-Whitney dapat dilihat pada Tabel 2. Uji Mann-Whitney menunjukkan hasil (sig $0,00<\alpha$ ) ini berarti $\mathrm{H}_{0}$ ditolak dan $\mathrm{H}_{1}$ diterima bahwa terdapat perbedaan kemampuan pemecahan masalah peserta didik antara yang diterapkan model pembelajaran Anchored Instruction dan model konvensional.

Tabel 2. Tes Statistik Uji Hipotesis

\begin{tabular}{cc}
\hline & Nilai \\
\hline Mann-Whitney U & 187.000 \\
Wilcoxon W & 652.000 \\
Z & -3.889 \\
Asymp. Sig. (2-tailed) & .000 \\
a. Grouping Variable: Test \\
\hline
\end{tabular}

Peningkatan kemampuan pemecahan masalah peserta didik dilihat dari nilai rata-rata pretest, posttest dan $\mathrm{N}$-gain pada kelas eksperimen dan kelas kontrol dapat dilihat pada Gambar 1.

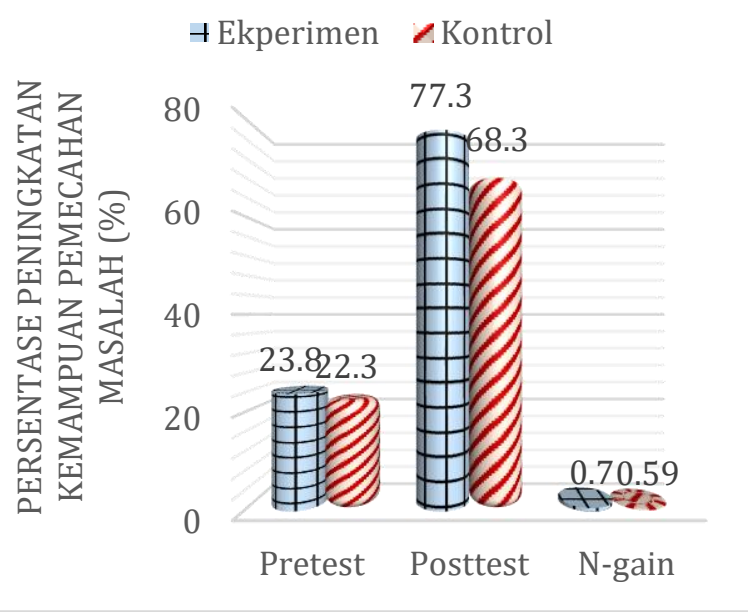

Gambar 1. Diagram Nilai Rata-Rata Kemampuan Pemecahan Masalah Peserta Didik

Berdasarkan diagram pada Gambar 1 terlihat bahwa kemampuan pemecahan masalah fisika peserta didik pada kelas eksperimen lebih tinggi dari kelas kontrol. Nilai N-gain pada kelas eksperimen mencapai kategori tinggi sedangkan pada kelas kontrol mencapai kategori sedang. Peningkatan kemampuan pemecahan masalah peserta didik untuk setiap sub konsep materi di kelas eksperimen dan kelas kontrol yang diteliti dapat dilihat pada Gambar 2.

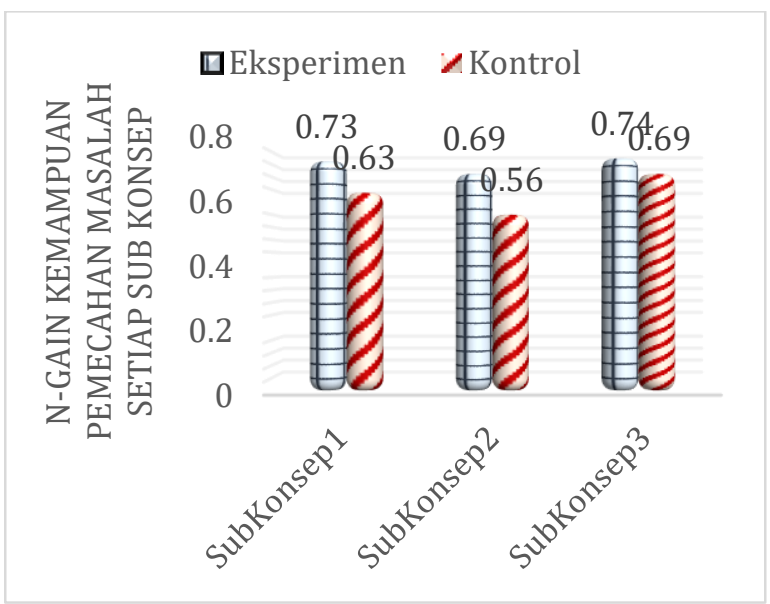

Gambar 2. Peningkatan N-Gain Setiap Sub Konsep pada Kelas Eksperimen dan Kelas Kontrol

\section{Keterangan:}

Sub konsep 1 = materi kalor

Sub konsep $2=$ materi perubahan wujud zat

Sub konsep 3 = materi perpindahan kalor

Berdasarkan diagram yang diperlihatkan pada Gambar 2 tentang kemampuan pemecahan masalah untuk setiap sub konsep yang diteliti, kelas eksperimen mencapai nilai yang lebih tinggi untuk setiap sub konsep dibandingkan kelas kontrol.

Peningkatan kemampuan pemecahan masalah fisika peserta didik untuk setiap indikator di kelas eksperimen dan kelas kontrol ditunjukkan dengan nilai N-Gain dapat dilihat pada Gambar 3. 


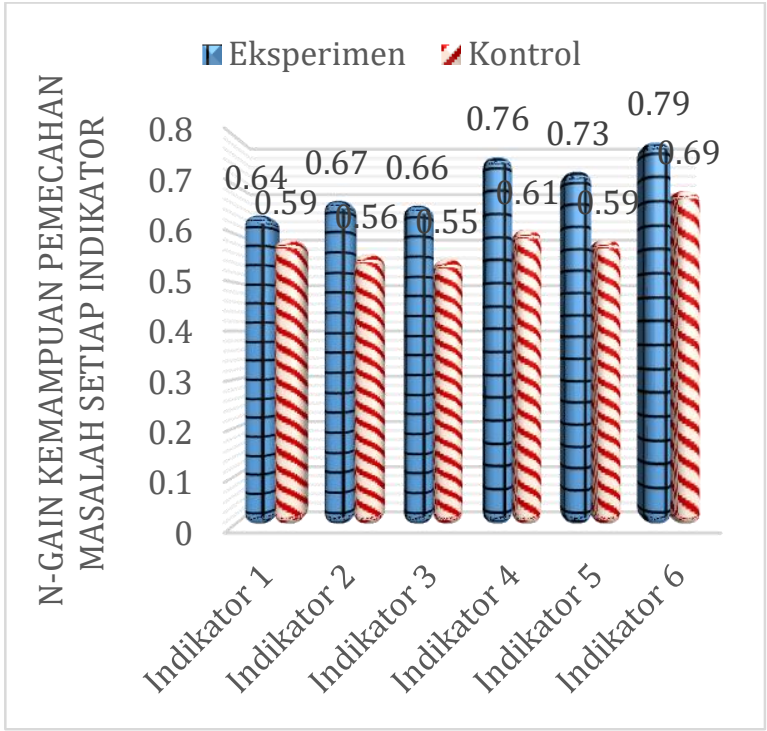

Gambar 3. Peningkatan N-Gain Setiap Indikator pada Kelas Eksperimen dan Kelas Kontrol

\section{Keterangan:}

Indikator $1=$ memahami masalah

Indikator $2=$ mengumpulkan data

Indikator $3=$ merumuskan hipotesis

Indikator $4=$ menguji hipotesis

Indikator $5=$ menilai hipotesis

Indikator 6 = menyimpulkan

Berdasarkan diagram yang diperlihatkan pada Gambar 3 tentang kemampuan pemecahan masalah untuk setiap indikator kemampuan pemecahan masalah yang diteliti, kelas eksperimen mencapai nilai yang lebih tinggi untuk setiap indikator dibandingkan kelas kontrol.

Semua peningkatan kemampuan pemecahan masalah peserta didik, baik secara menyeluruh, setiap sub konsep materi, maupun setiap indikator pencapaian, menunjukkan kelas eksperimen mencapai nilai lebih tinggi dibandingkan kelas kontrol. Hal ini menunjukkan bahwa model pembelajaran Anchored Instruction di kelas eksperimen dapat meningkatkan kemampuan pemecahan masalah fisika peserta didik pada materi kalor. Hal ini sejalan dengan apa yang disampaikan oleh Shyu (2000) bahwa model pembelajaran Anchored Instruction bertujuan untuk membantu peserta didik mengembangkan kepercayaan diri, keterampilan, dan pengetahuan yang diperlukan untuk memecahkan masalah dan menjadi pemikir independen.

\section{KESIMPULAN}

Berdasarkan hasil penelitian dan pembahasan yang telah dilakukan, kesimpulan penelitian ini adalah terdapat pengaruh positif dari model pembelajaran Anchored Instruction dan konvensional terhadap peningkatan kemampuan pemecahan masalah peserta didik. Kemampuan pemecahan masalah peserta didik yang belajar dengan model pembelajaran Anchored Instruction mencapai nilai lebih tinggi daripada peserta didik yang belajar dengan model konvensional.

\section{DAFTAR PUSTAKA}

Sanjaya, Wina, 2006. Strategi pembelajaran Berorientasi Proses Standar Pendidikan, Jakarta: Penerbit KENCANA

Trianto, Ibnu Badar. 2014. Mendesain Model Pembelajaran Inovatif, Progresif, dan Kontekstual. Jakarta: Penerbit Prenadamedia Group

Nasution. 2009. Berbagai Pendekatan dalam Proses Belajar dan Mengajar. Jakarta: Penerbit Bumi Aksara

Bransford, Goldman, dan Biswas. 1997. Anchored Interactive Learning Environments, Journal of AI in Education,.8 : 1-31

Oliver, K. 1999, "Anchored Instruction", http://www.edtech.vt.edu/edtech/id, [diakses 18 November 2015 pukul $17.45 \mathrm{wib}]$

Ellyna Hafizah. 2014. Pengaruh Model Pembelajaran Anchored Instruction Terhadap Penguasaan Konsep dan Kemampuan Pemecahan Masalah Fisika Siswa Kelas X. Jurnal Fisika Indonesia, XVIII (52) , Edisi April 2014. ISSN : 1410-2994. 
Kovalchick, Ann dan Kara Dawson (Eds). 2004. Education and Technology an Encyclopedia. Santa Bara.

Shyu, Hsin-Yih Cindy. 2000. Using VideoBased Anchored Instruction To Enhance Learning: Taiwan's Experience. British Journal of Educational Technology. 31(1) : 57-69.

Tawil dan Liliasari. 2013. Berpikir Kompleks dan Implementasinya dalam Pembelajaran IPA. Makasar: Penerbit UNM 